\title{
Behavioral Abnormality Induced by Enhanced Hypothalamo-Pituitary-Adrenocortical Axis Activity under Dietary Zinc Deficiency and Its Usefulness as a Model
}

\author{
Atsushi Takeda *, Haruna Tamano, Ryusuke Nishio and Taku Murakami \\ Department of Neurophysiology, School of Pharmaceutical Sciences, University of Shizuoka, 52-1 Yada, \\ Suruga-ku, Shizuoka 422-8526, Japan; tamano@u-shizuoka-ken.ac.jp (H.T.); s16114@u-shizuoka-ken.ac.jp (R.N.); \\ s16115@u-shizuoka-ken.ac.jp (T.M.) \\ * Correspondence: takedaa@u-shizuoka-ken.ac.jp; Tel.: +81-54-264-5733
}

Academic Editor: Sotiris Hadjikakou

Received: 8 June 2016; Accepted: 9 July 2016; Published: 16 July 2016

\begin{abstract}
Dietary zinc deficiency increases glucocorticoid secretion from the adrenal cortex via enhanced hypothalamo-pituitary-adrenocortical (HPA) axis activity and induces neuropsychological symptoms, i.e., behavioral abnormality. Behavioral abnormality is due to the increase in glucocorticoid secretion rather than disturbance of brain zinc homeostasis, which occurs after the increase in glucocorticoid secretion. A major target of glucocorticoids is the hippocampus and their actions are often associated with disturbance of glutamatergic neurotransmission, which may be linked to behavioral abnormality, such as depressive symptoms and aggressive behavior under zinc deficiency. Glucocorticoid-mediated disturbance of glutamatergic neurotransmission in the hippocampus is also involved in the pathophysiology of, not only psychiatric disorders, such as depression, but also neurodegenerative disorders, e.g., Alzheimer's disease. The evidence suggests that zinc-deficient animals are models for behavioral and psychological symptoms of dementia (BPSD), as well as depression. To understand validity to apply zinc-deficient animals as a behavioral abnormality model, this paper deals with the effect of antidepressive drugs and herbal medicines on hippocampal dysfunctions and behavioral abnormality, which are induced by enhanced HPA axis activity under dietary zinc deficiency.
\end{abstract}

Keywords: zinc deficiency; glucocorticoid; hippocampus; glutamate excitotoxicity; behavioral and psychological symptoms of dementia; herbal medicine

\section{Introduction}

Brain zinc homeostasis is critical for brain function [1]. However, the hormones for regulating zinc homeostasis are unknown and the mechanism for regulating zinc homeostasis remains to be clarified. Dietary zinc deficiency leads to a reduction in total food intake. The reduction occurs within approximately three days [2]. The reduction in plasma zinc level also occurs at this time (Figure 1) [3]. Although zinc deficiency-induced anorexia is well known [4], the mechanism is unclear. Zinc deficiency elevates the hypothalamo-pituitary-adrenocortical (HPA) axis activity, followed by an increase in glucocorticoid secretion from the adrenal cortex [5,6], which is involved in stress response (Figure 1) [7]. The continuous increase in plasma corticosterone concentration is observed after daily administration of a zinc-deficient diet [8,9]. Brain zinc homeostasis is resistant to dietary zinc deficiency. However, chronic zinc deficiency decreases extracellular zinc concentration in the hippocampus and then decreases zinc concentration in the synaptic vesicles $[10,11]$. Free $\mathrm{Zn}^{2+}$ may be the most responsive to zinc deficiency, and the decrease in plasma $\mathrm{Zn}^{2+}$ might be linked to corticosterone secretion. 


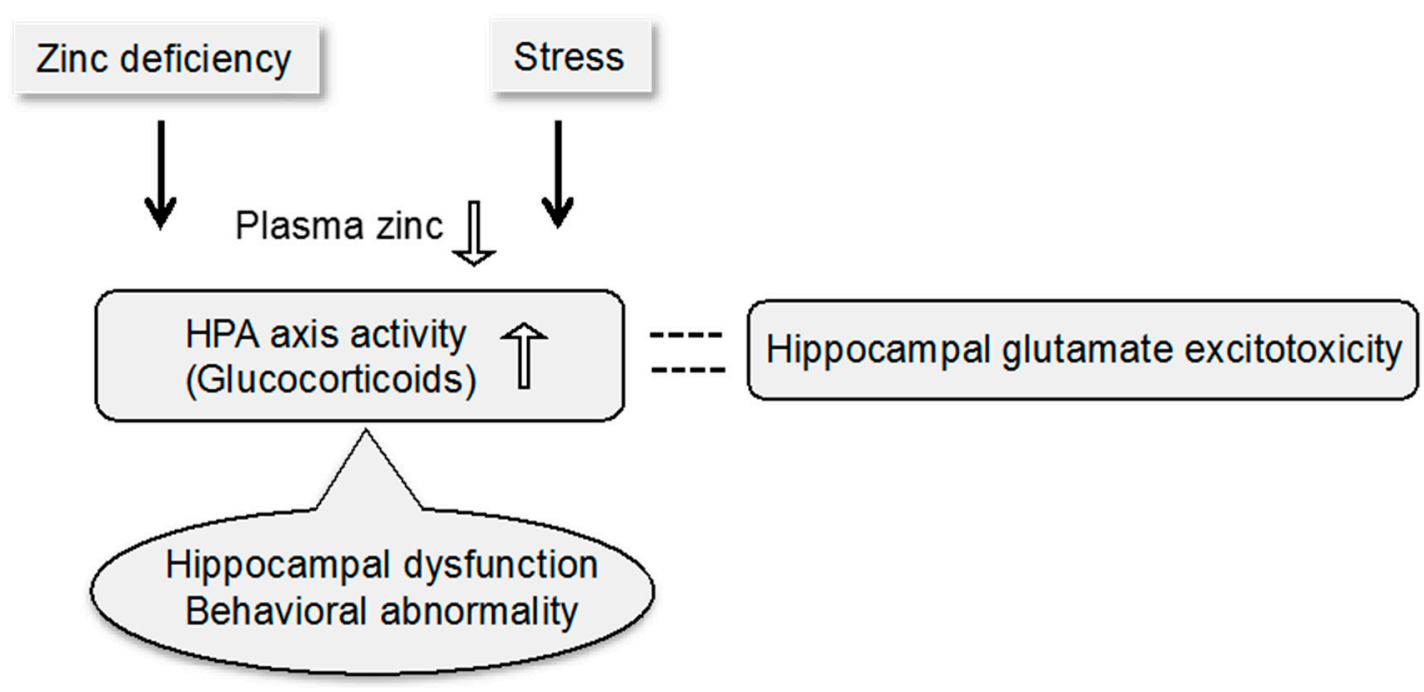

Figure 1. Behavioral abnormality, which is induced by enhanced HPA axis activity under dietary zinc deficiency, as models for depressive symptoms and BPSD. The black arrow, causative action; the white arrow, decreased and increased concentrations; dashed line, close relationship.

All neurons have glutamate receptors in the brain. The extracellular concentration of glutamate is approximately $2 \mu \mathrm{M}$ in the brain, while glutamate concentration in the synaptic vesicles of glutamatergic neurons reaches approximately $100 \mathrm{mM}$ [12]. Extracellular glutamate signaling is critical for not only synaptic function such as synaptic plasticity but also synaptic dysfunction such as excitotoxicity [13,14]. Excess activation of glutamate receptors results in deleterious consequences such as calcium buffering impairment, free radical generation, the mitochondrial permeability transition activation, and secondary excitotoxicity $[15,16]$. Glutamate excitotoxicity is a final common pathway leading to neuronal death and observed in many neurological disorders including stroke/ischemia, temporal lobe epilepsy, Parkinson's disease, amyotrophic lateral sclerosis, and Alzheimer's disease [17-19].

Stress also elevates the HPA axis activity and increases glucocorticoid secretion, which buffers stress (Figure 1). The hippocampus regulates the HPA axis activity and is involved in the negative feedback mechanism of glucocorticoid secretion. The regulation is linked to cognitive and emotional behavior [20]. The HPA axis activity is also elevated in normal aging [21,22] and neurological disorders [23]. Hippocampal neurons are vulnerable to the pathological elevation of the HPA axis activity, which is linked to the occurrence and progression of cognitive disorders [24]. Furthermore, there are correlations between increase in glucocorticoid secretion and dementia severity or hippocampal atrophy in patients with probable Alzheimer's disease [25]. Correlations are also reported between increase in glucocorticoid secretion and depression severity or hippocampal atrophy in patients with depression [26].

The hippocampus is vulnerable to zinc deficiency [27] and neuropsychological symptoms associated with enhanced HPA axis activity are observed in zinc-deficient animals $[28,29]$. The evidence suggests that zinc-deficient animals are models for psychiatric disorders. To understand the validity of applying zinc-deficient animals as a behavioral abnormality model, this paper deals with the effect of antidepressive drugs and herbal medicines on hippocampal dysfunctions and behavioral abnormality, which are induced by enhanced HPA axis activity under dietary zinc deficiency.

Dietary zinc deficiency and stress decrease serum zinc level [3] and enhanced HPA axis activity [5-7]. The chronic increase in glucocorticoid secretion by enhanced HPA axis activity induces hippocampal dysfunction and behavioral abnormality, which may be models for depressive symptoms and behavioral and psychological symptoms of dementia (BPSD), and is linked to responsibility to glutamate excitotoxicity in the hippocampus (Figure 1). 


\section{Hippocampus as a Major Target of Glucocorticoids}

The hippocampus is a major target of glucocorticoids and is enriched with corticosteroid receptors [30,31]. Mineralocorticoid receptors are usually occupied with low levels of cortisol in humans (corticosterone in rats). Glucocorticoid receptors are markedly activated after exposure to stress [32]. Glucocorticoids readily increase glutamate release from neuron terminals in the hippocampus via the mechanism that may involve membrane-associated mineralocorticoid receptors. As an indirect mechanism, glucocorticoids can modify glutamatergic neuron activity via cross talk with the endocannabinoid system [33]. The rapid effects of glucocorticoids on synaptic activity may be linked to the diverse effects on memory processes through synaptic plasticity in the hippocampus. Acute stress induces synaptic insertion of calcium-permeable $\alpha$-amino-3-hydroxy-5-methyl-4-isoxazolepropionate (AMPA) receptors, which facilitates long-term potentiation (LTP) in the hippocampus [34]. On the other hand, corticosterone-mediated blockade of glutamate transporters leads to glutamate accumulation in the extracellular compartment at high levels when abnormal corticosterone secretion is induced under severe stress. Abnormal corticosterone secretion also induces excess release of glutamate from neuron terminals in the hippocampus $[35,36]$. The spillover of glutamate in the extracellular compartment impairs spatial memory retrieval.

Glucocorticoid concentration in the plasma is higher in aged animals than young animals [21]. The nocturnal levels of cortisol are increased in aged humans [22]. Furthermore, high cortisol levels are observed in Alzheimer's disease and depression. In patients with Alzheimer's disease, core symptoms, e.g., cognitive deficits and BPSD, e.g., aggression, hallucinations, disturbed behavior, and agitation are linked to dysregulation of the HPA axis activity $[37,38]$. Excess cortisol secretion is linked to cognitive decline in normal aging, in addition to neurological disorders such as dementia. Therefore, zinc deficiency may become a risk factor for the pathogenesis of Alzheimer's disease and depression. Zinc-deficient animals may be models to assess the effect of drugs on hippocampal dysfunctions and behavioral abnormality, which are associated with elevated HPA axis activity.

\section{Vulnerability of Hippocampus to Glutamate Excitotoxicity and Its Enhancement by Zinc Deficiency}

It is well known that the hippocampus is vulnerable to glutamate excitotoxicity. Hippocampal neuronal death is reported in temporal lobe epilepsy, in which epileptic seizures frequently occur in the hippocampus [39]. When extracellular glutamate is increased in the hippocampus, the increase may trigger epileptic seizures in patients with complex partial epilepsy [40]. Brain zinc homeostasis is closely linked to the pathophysiology of epileptic seizures [41]. In global ischemia, potassium concentration transiently reaches $75 \mathrm{mM}$ in the extracellular compartment and the increase leads to glutamate accumulation in the extracellular compartment [42]. Reversed operation of glial glutamate transporter, GLT-1, which may be induced with energy (ATP) depletion, is involved in the accumulation of extracellular glutamate in ischemia, which is crucial to excitotoxic death of neurons [43]. High $\mathrm{K}^{+}$-mediated increase in extracellular glutamate is enhanced in the hippocampus of zinc-deficient rats $[10,44]$. Neurological disorders, such as epilepsy and ischemia, seem to be aggravated by the enhanced glutamate excitotoxicity under zinc deficiency $[11,45,46]$.

Excess glucocorticoid secretion may modify glutamate neurotransmission in the hippocampus under zinc deficiency [47]. Glucocorticoids elevate voltage-dependent calcium conductance, in addition to calcium-dependent afterhyperpolarization [48,49]. $\mathrm{Ca}^{2+}$ mobilization is modified in hippocampal neurons with glucocorticoids; $\mathrm{Ca}^{2+}$ mobilization into the cytosolic compartment is increased by glucocorticoids, while its removal is decreased by glucocorticoids [50]. Cytosolic $\mathrm{Ca}^{2+}$ concentration in the hippocampus is increased in brain slices prepared from zinc-deficient animals [8,51]. Glucocorticoid-mediated modification of intracellular $\mathrm{Ca}^{2+}$ dynamics seems to be linked to hippocampal function under zinc deficiency (Figure 2). Presynaptic activity (exocytosis) is elevated at hippocampal mossy fiber synapses in brain slices prepared from zinc-deficient rats [44]. 
Modification of $\mathrm{Ca}^{2+}$ signaling via the increase in the basal level of $\mathrm{Ca}^{2+}$ is reported in hippocampal neurons of aged animals [52,53]. Serum zinc level is significantly lower in aged animals than in young animals, while zinc concentration in the brain of aged animals and humans is almost the same as that of young animals and humans [54-57]. Glucocorticoid secretion, which is increased by aging and zinc deficiency, is linked to glutamatergic neuron activity in the hippocampus. Thus, the increased secretion may contribute to susceptibility to glutamate excitotoxicity in elderly and zinc-deficient people (Figure 1).

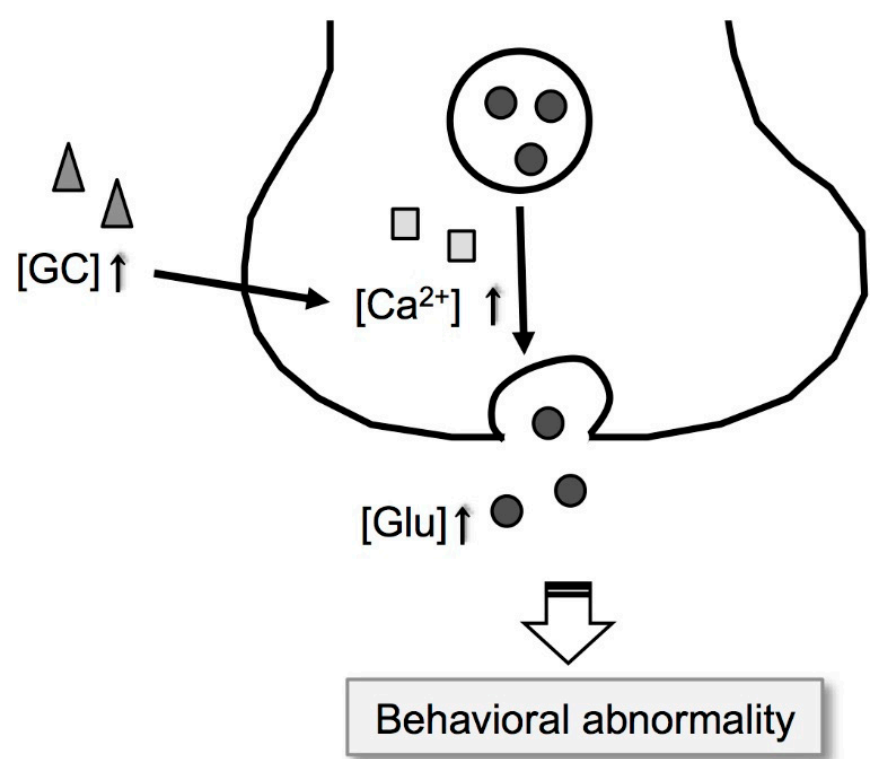

Figure 2. Modification of glutamate signaling via glucocorticoid signaling under dietary zinc deficiency. Extracellular glucocorticoid [GC] concentration in the hippocampus increased by dietary zinc deficiency can elevate glutamatergic neuron activity via modification of intracellular $\mathrm{Ca}^{2+}$ signaling as shown by the two long black arrows. Grey triangle, grey square, and grey circle show increases in extracellular $\mathrm{GC}$, intracellular $\mathrm{Ca}^{2+}$, and extracellular glutamate, respectively.

\section{Zinc Deficiency and Depression}

The regulation of the HPA axis activity is affected in approximately $50 \%$ of human depressives [58]. Interestingly, it is reported that human depressives are zinc-deficient $[59,60]$. The increase in depression-like behavior has been reported in zinc-deficient mice [61] and rats [62]. The symptoms are observed without appreciably decreasing zinc concentration in the brain [63,64]. Depressive symptoms are also reported in sheep and goats [65]. Anxiety- and depression-like behavior is increased in mice and rats after repeated injections of corticosterone [66,67]. The contentious increase in corticosterone under dietary zinc deficiency may be linked to depression-like behavior.

Stress reduces hippocampal neurogenesis and reduced neurogenesis is associated with the pathophysiology of depression [68,69]. Antiglucocorticoids such as conventional antidepressants can ameliorate depressive symptoms via elevating hippocampal neurogenesis [70,71]. Decreased brain zinc availability under chronic zinc deficiency reduces hippocampal neurogenesis in mice and rats [72], and might be related to the pathophysiology of depression. Abnormal secretion of glucocorticoid induced by chronic stress has been observed in many neuropsychiatric disorders such as depression [73,74]. Neuropsychiatric disorders are exacerbated by exposure to stress. The hippocampus is vulnerable to stress-related disorders [30,31]. The interplay between glutamatergic neurotransmission in the hippocampus and the chronic or excess exposure to glucocorticoids plays a key role for pathogenesis of depression (Figure 1) [75].

Serum zinc concentration is decreased in patients with depression [59,76], while effective antidepressant treatment normalizes the decrease in serum zinc [77]. Zinc supplementation is effective 
for antidepressant therapy using drugs, such as selective serotonin reuptake inhibitors [78,79], while zinc deficiency reduces responsiveness to antidepressant drugs in mice [80]. Administration of glutamate receptor antagonists, including zinc, shows antidepressant effect in preclinical and clinical studies [81]. Zinc also has a robust effect on reversing behavioral alteration induced by chronic unpredictable stress in mice, possibly through the modulation of glutamatergic neurotransmission [82]. The decrease in serum zinc may be a state marker of depression [78].

\section{Zinc Deficiency and Behavioral and Psychological Symptoms of Dementia (BPSD)}

Externalizing behaviors, such as aggression, hyperactivity, and conduct disorder, have been viewed as a public health problem in childhood based on its etiology and outcome. Poor nutrition such as zinc deficiency is involved in the development of behavioral abnormality in childhood [83]. Zinc deficiency might be associated with assaultive behavior of young men. Plasma copper/zinc ratios are elevated in assaultive young males [84]. In experimental animals, social isolation is an effective method of inducing aggressive behavior. Social isolation-induced aggressive behavior is significantly increased in zinc-deficient young mice [9]. In contrast, neuropsychological behaviors are improved in school-age children with zinc supplementation $[85,86]$.

Yokukansan is a traditional Japanese herbal medicine and a remedy for insomnia, irritability, and neurosis in children. The clinical effectiveness of Yokukansan has also been reported in patients with dementia including Alzheimer's disease [87-89]. BPSD is a major problem for caregivers [90] and its severity is positively correlated with the care burden. Curing BPSD is important for both patients and caregivers [91,92]. More than $60 \%$ of patients with Alzheimer's disease show agitation and aggression [93], which are the primary cause of hospitalization [94]. Yokukansan is an effective drug to cure BPSD [87-91]. Disturbed glutamatergic neuron activity in the hippocampus might underlie both BPSD and core symptoms [95]. On the basis of the evidence that zinc deficiency-induced modification of glucocorticoid secretion disturbs glutamatergic neuron activity in the hippocampus and induces behavioral abnormality (Figure 1) [96], zinc-deficient animals have been used to estimate the action mechanism of Yokukansan on BPSD. Administration of Yokukansan to zinc-deficient mice ameliorates social isolation-induced aggressive behavior, potentially via ameliorating abnormal glutamatergic neuron activity in the hippocampus [44,97-99]. Administration of Yokukansankachimpihange, a potential herbal medicine for BPSD, to zinc-deficient mice also ameliorates social isolation-induced aggressive behavior. The two common ingredients ameliorate abnormal glutamatergic neuron activity in the hippocampus [100]. It is likely that zinc-deficient animals are models to assess the effect of drugs on behavioral abnormality, such as BPSD.

\section{Conclusions and Perspective}

The evidence suggests that zinc-deficient animals are useful models for behavioral abnormality such as depressive symptoms and BPSD. The disturbance of glutamatergic neurotransmission in the hippocampus, which is induced by enhanced HPA axis activity under dietary zinc deficiency, underlies behavioral abnormality (Figures 1 and 2).

On the other hand, diabetes mellitus chronically increase the HPA axis activity, which may contribute to insulin resistance [101]. Depression-like behavior is observed in GPR39 $\left(\mathrm{Zn}^{2+}\right.$-sensing receptor) knockout mice without an increase in serum corticosterone [102]. Huang et al. [103] report that the serious effects on rat brain development induced by marginal zinc deficiency may not be linked with fetal exposure to excess maternal glucocorticoids. Therefore, further investigation on the involvement of other endocrine systems in behavioral abnormality caused under zinc deficiency is necessary for validity as experimental models.

Author Contributions: Atsushi Takeda wrote the manuscript. Haruna Tamano, Ryusuke Nishio and Taku Murakami confirmed the content.

Conflicts of Interest: The authors declare no conflict of interest. 


\section{References}

1. Sandstead, H.H.; Frederickson, C.J.; Penland, J.G. History of zinc as related to brain function. J. Nutr. 2000, 130, 496S-502S. [PubMed]

2. Evans, S.A.; Overton, J.M.; Alshingiti, A.; Levenson, C.W. Regulation of metabolic rate and substrate utilization by zinc deficiency. Metabolism 2004, 53, 727-732. [CrossRef] [PubMed]

3. Ohinata, K.; Takemoto, M.; Kawanago, M.; Fushimi, S.; Shirakawa, H.; Goto, T.; Asakawa, A.; Komai, M. Orally administered zinc increases food intake via vagal stimulation in rats. J. Nutr. 2009, 139, 611-616. [CrossRef] [PubMed]

4. Shay, N.F.; Mangian, H.F. Neurobiology of zinc-influenced eating behavior. J. Nutr. 2000, 130 (Suppl. S5), 1493S-1499S. [PubMed]

5. Fraker, P.J.; Osati-Ashtiani, F.; Wagner, M.A.; King, L.E. Possible roles for glucocorticoids and apoptosis in the suppression of lymphopoiesis during zinc deficiency: A review. J. Am. Coll. Nutr. 1995, 14, 11-17. [CrossRef] [PubMed]

6. King, L.E.; Osati-Ashtiani, F.; Fraker, P.J. Apoptosis plays a distinct role in the loss of precursor lymphocytes during zinc deficiency in mice. J. Nutr. 2002, 132, 974-979. [PubMed]

7. Chrousos, G.P.; Gold, P.W. The concepts of stress and stress system disorders: Overview of physical and behavioral homeostasis. J. Am. Med. Assoc. 1992, 267, 1244-1252. [CrossRef]

8. Takeda, A.; Tamano, H.; Kan, F.; Itoh, H.; Oku, N. Anxiety-like behavior of young rats after 2-week zinc deprivation. Behav. Brain Res. 2007, 177, 1-6. [CrossRef] [PubMed]

9. Takeda, A.; Tamano, H.; Kan, F.; Hanajima, T.; Yamada, K.; Oku, N. Enhancement of social isolation-induced aggressive behavior of young mice by zinc deficiency. Life Sci. 2008, 82, 909-914. [CrossRef] [PubMed]

10. Takeda, A.; Hirate, M.; Tamano, H.; Oku, N. Release of glutamate and GABA in the hippocampus under zinc deficiency. J. Neurosci. Res. 2003, 72, 537-542. [CrossRef] [PubMed]

11. Takeda, A.; Hirate, M.; Tamano, H.; Nishibaba, D.; Oku, N. Susceptibility to kainate-induced seizures under dietary zinc deficiency. J. Neurochem. 2003, 85, 1575-1580. [CrossRef] [PubMed]

12. Meldrum, B.S. Glutamate as a neurotransmitter in the brain: Review of physiology and pathology. J. Nutr. 2000, 130, 1007S-1015S. [PubMed]

13. Collingridge, G.L.; Lester, R.A.J. Excitatory amino acid receptors in the vertebrate central nervous system. Pharmacol. Rev. 1989, 40, 143-210.

14. Headley, P.M.; Grillner, S. Excitatory amino acids and synaptic transmission: The evidence for a physiological function. Trends Pharmacol. Sci. 1990, 11, 205-211. [CrossRef]

15. Danbolt, N.C. Glutamate uptake. Prog. Neurobiol. 2001, 65, 1-105. [CrossRef]

16. Dong, X.X.; Wang, Y.; Qin, Z.H. Molecular mechanisms of excitotoxicity and their relevance to pathogenesis of neurodegenerative diseases. Acta Pharmacol. Sin. 2009, 30, 379-387. [CrossRef] [PubMed]

17. Choi, D.W.; Rothman, S.M. The role of glutamate neurotoxicity in hypoxic-ischemic neuronal death. Annu. Rev. Neurosci. 1990, 13, 171-182. [CrossRef] [PubMed]

18. Lipton, S.A.; Rosenberg, P.A. Excitatory amino acids as a final common pathway for neurologic disorders. N. Engl. J. Med. 1994, 330, 613-622. [PubMed]

19. Obrenovitch, T.P.; Urenjak, J. Altered glutamatergic transmission in neurological disorders: From high extracellular glutamate to excessive synaptic efficacy. Prog. Neurobiol. 1997, 51, 39-87. [CrossRef]

20. Sandi, C. Glucocorticoids act on glutamatergic pathways to affect memory processes. Trends Neurosci. 2011, 34, 165-176. [CrossRef] [PubMed]

21. Landfield, P.W.; Eldridge, J.C. Evolving aspects of the glucocorticoid hypothesis of brain aging: Hormonal modulation of neuronal calcium homeostasis. Neurobiol. Aging 1994, 15, 579-588. [CrossRef]

22. Ferrari, E.; Casarotti, D.; Muzzoni, B.; Albertelli, N.; Cravello, L.; Fioravanti, M.; Solerte, S.B.; Magri, F. Age-related changes of the adrenal secretory pattern: Possible role in pathological brain aging. Brain Res. Rev. 2001, 37, 294-300. [CrossRef]

23. Nicolaides, N.C.; Kyratzi, E.; Lamprokostopoulou, A.; Chrousos, G.P.; Charmandari, E. Stress, the stress system and the role of glucocorticoids. Neuroimmunomodulation 2015, 22, 6-19. [CrossRef] [PubMed]

24. Magri, F.; Cravello, L.; Barili, L.; Sarra, S.; Cinchetti, W.; Salmoiraghi, F.; Micale, G.; Ferrari, E. Stress and dementia: The role of the hypothalamicpituitary-adrenal axis. Aging Clin. Exp. Res. 2006, 18, 167-170. [CrossRef] [PubMed] 
25. Csernansky, J.G.; Dong, H.; Fagan, A.M.; Wang, L.; Xiong, C.; Holtzman, D.M.; Morris, J.C. Plasma cortisol and progression of dementia in subjects with Alzheimer-type dementia. Am. J. Psychiatry 2006, 163, 2164-2169. [CrossRef] [PubMed]

26. O’Brien, J.T.; Ames, D.; Schweitzer, I.; Colman, P.; Desmond, P.; Tress, B. Clinical and magnetic resonance imaging correlates of hypothalamic-pituitary-adrenal axis function in depression and Alzheimer's disease. Br. J. Psychiatry 1996, 168, 679-687. [CrossRef] [PubMed]

27. Takeda, A.; Minami, A.; Takefuta, S.; Tochigi, M.; Oku, N. Zinc homeostasis in the brain of adult rats fed zinc-deficient diet. J. Neurosci. Res. 2001, 63, 447-452. [CrossRef]

28. Takeda, A.; Tamano, H. Insight into zinc signaling from dietary zinc deficiency. Brain Res. Rev. 2009, 62, 33-34. [CrossRef] [PubMed]

29. Takeda, A. Zinc signaling in the hippocampus and its relation to pathogenesis of depression. Mol. Neurobiol. 2011, 44, 167-174. [CrossRef] [PubMed]

30. Kawata, M.; Yuri, K.; Ozawa, H.; Nishi, M.; Ito, T.; Hu, Z.; Lu, H.; Yoshida, M. Steroid hormones and their receptors in the brain. J. Steroid Biochem. Mol. Biol. 1998, 65, 273-280. [CrossRef]

31. Joëls, M. Functional actions of corticosteroids in the hippocampus. Eur. J. Pharmacol. 2008, 583, 312-321. [CrossRef] [PubMed]

32. Joëls, M.; Karst, H.; DeRijk, R.; de Kloet, E.R. The coming out of the brain mineralocorticoid receptor. Trends Neurosci. 2008, 31, 1-7. [CrossRef] [PubMed]

33. McEwen, B.S.; Bowles, N.P.; Gray, J.D.; Hill, M.N.; Hunter, R.G.; Karatsoreos, I.N.; Nasca, C. Mechanisms of stress in the brain. Nat. Neurosci. 2015, 18, 1353-1363. [CrossRef] [PubMed]

34. Whitehead, G.; Jo, J.; Hogg, E.L.; Piers, T.; Kim, D.H.; Seaton, G.; Seok, H.; Bru-Mercier, G.; Son, G.H.; Regan, P.; et al. Acute stress causes rapid synaptic insertion of $\mathrm{Ca}^{2+}$-permeable AMPA receptors to facilitate long-term potentiation in the hippocampus. Brain 2013, 136, 3753-3765. [CrossRef] [PubMed]

35. Wong, T.P.; Howland, J.G.; Robillard, J.M.; Ge, Y.; Yu, W.; Titterness, A.K.; Brebner, K.; Liu, L.; Weinberg, J.; Christie, B.R.; et al. Hippocampal long-term depression mediates acute stress-induced spatial memory retrieval impairment. Proc. Natl. Acad. Sci. USA 2007, 104, 11471-11476. [CrossRef] [PubMed]

36. Howland, J.G.; Wang, Y.T. Synaptic plasticity in learning and memory: Stress effects in the hippocampus. Prog. Brain Res. 2008, 169, 145-158. [PubMed]

37. Swanwick, G.R.J.; Kirby, M.; Bruce, I.; Buggy, F.; Coen, R.F.; Coakley, D.; Lawlor, B.A. Hypothalamic-pituitary-adrenal axis dysfunction in Alzheimer's disease: Lack of association between longitudinal and cross-sectional findings. Am. J. Psychiatry 1998, 155, 286-289. [PubMed]

38. Brureau, A.; Zussy, C.; Delair, B.; Ogier, C.; Ixart, G.; Maurice, T.; Givalois, L. Deregulation of hypothalamic-pituitary-adrenal axis functions in an Alzheimer's disease rat model. Neurobiol. Aging 2013, 34, 1426-1439. [CrossRef] [PubMed]

39. Seyfried, T.N.; Glaser, G.H. A review of mouse mutants as genetic models of epilepsy. Epilepsia 1985, 26, 143-150. [CrossRef] [PubMed]

40. During, M.J.; Spencer, D.D. Extracellular hippocampal glutamate and spontaneous seizure in the conscious human brain. Lancet 1993, 341, 1607-1610. [CrossRef]

41. Saghazadeh, A.; Mahmoudi, M.; Meysamie, A.; Gharedaghi, M.; Zamponi, G.W.; Rezaei, N. Possible role of trace elements in epilepsy and febrile seizures: A meta-analysis. Nutr. Rev. 2015, 73, 760-779. [CrossRef] [PubMed]

42. Hansen, A.J.; Zeuthen, T. Extracellular ion concentrations during spreading depression and ischemia in the rat brain cortex. Acta Physiol. Scand. 1980, 113, 437-445. [CrossRef] [PubMed]

43. Kosugi, T.; Kawahara, K. Reversed actrocytic GLT-1 during ischemia is crucial to excitotoxic death of neurons, but contributes to the survival of astrocytes themselves. Neurochem. Res. 2006, 31, 933-943. [CrossRef] [PubMed]

44. Takeda, A.; Tamano, H.; Itoh, H.; Oku, N. Attenuation of abnormal glutamate release in zinc deficiency by zinc and Yokukansan. Neurochem. Int. 2008, 53, 230-235. [CrossRef] [PubMed]

45. Takeda, A.; Tamano, H.; Nagayoshi, A.; Yamada, K.; Oku, N. Increase in hippocampal cell death after treatment with kainate in zinc deficiency. Neurochem. Int. 2005, 47, 539-544. [CrossRef] [PubMed]

46. Stoltenberg, M.; Bush, A.I.; Bach, G.; Smidt, K.; Larsen, A.; Rungby, J.; Lund, S.; Doering, P.; Danscher, G. Amyloid plaques arise from zinc-enriched cortical layers in APP/PS1 transgenic mice and are paradoxically enlarged with dietary zinc deficiency. Neuroscience 2007, 150, 357-369. [CrossRef] [PubMed] 
47. Stein-Behrens, B.A.; Elliott, E.M.; Miller, C.A.; Schilling, J.W.; Newcombe, R.; Sapolsky, R.M. Glucocorticoids exacerbate kainic acid-induced extracellular accumulation of excitatory amino acids in the rat hippocampus. J. Neurochem. 1992, 58, 1730-1735. [CrossRef] [PubMed]

48. Landfield, P.W.; Pitler, T.A. Prolonged $\mathrm{Ca}^{2+}$-dependent afterhyperpolarizations in hippocampal neurons of aged rats. Science 1984, 226, 1089-1092. [CrossRef] [PubMed]

49. Kerr, D.S.; Campbell, L.W.; Thibault, O.; Landfield, P.W. Hippocampal glucocorticoid receptor activation enhances voltage-dependent $\mathrm{Ca}^{2+}$ conductances: Relevance to brain aging. Proc. Natl. Acad. Sci. USA 1992, 89, 8527-8531. [CrossRef] [PubMed]

50. Bhargava, A.; Meijer, O.C.; Dallman, M.F.; Pearce, D. Plasma membrane calcium pump isoform 1 gene expression is repressed by corticosterone and stress in rat hippocampus. J. Neurosci. 2000, 20, 3129-3138. [PubMed]

51. Takeda, A.; Yamada, K.; Tamano, H.; Fuke, S.; Kawamura, M.; Oku, N. Hippocampal calcium dyshomeostasis and long-term potentiation in 2-week zinc deficiency. Neurochem. Int. 2008, 52, 241-246. [CrossRef] [PubMed]

52. Billard, J.M. Ageing, hippocampal synaptic activity and magnesium. Magnes Res. 2006, 19, $199-215$. [PubMed]

53. Foster, T.C. Calcium homeostasis and modulation of synaptic plasticity in the aged brain. Aging Cell 2007, 6, 319-325. [CrossRef] [PubMed]

54. Takeda, A.; Sakurada, N.; Kanno, S.; Ando, M.; Oku, N. Vulnerability to seizures induced by potassium dyshomeostasis in the hippocampus in aged rats. J. Health Sci. 2008, 54, 37-42. [CrossRef]

55. Markesbery, W.R.; Ehmann, W.D.; Alauddin, M.; Hossain, T.I.M. Brain trace element concentrations in aging. Neurobiol. Aging 1984, 5, 19-28. [CrossRef]

56. Mocchegiani, E.; Giacconi, R.; Cipriano, C.; Muti, E.; Gasparini, N.; Malavolta, M. Are zinc-bound metallothionein isoforms (I + II and III) involved in impaired thymulin production and thymic involution during ageing? Immun. Ageing 2004, 1, 5. [CrossRef] [PubMed]

57. Idei, M.; Miyake, K.; Horiuchi, Y.; Tabe, Y.; Miyake, N.; Ikeda, N.; Miida, T. Serum zinc concentration decreases with age and is associated with anemia in middle-aged and elderly people. Rinsho Byori 2010, 58, 205-210. [PubMed]

58. Arana, G.W.; Baldessarini, R.J.; Ornsteen, M. The dexamethasone suppression test for diagnosis and prognosis in psychiatry. Arch. Gen. Psychiatry 1985, 42, 1193-1204. [CrossRef] [PubMed]

59. Maes, M.; D’Haese, P.C.; Scharpé, S.; D’Hondt, P.; Cosyns, P.; de Broe, M.E. Hypozincemia in depression. J. Affect. Disord. 1994, 31, 135-140. [CrossRef]

60. Nowak, G.; Szewczyk, B.; Pilc, A. Zinc and depression. An update. Pharmacol. Rep. 2005, 57, 713-718. [PubMed]

61. Whittle, N.; Lubec, G.; Singewald, N. Zinc deficiency induces enhanced depression-like behaviour and altered limbic activation reversed by antidepressant treatment in mice. Amino Acids 2009, 36, 147-158. [CrossRef] [PubMed]

62. Tassabehji, N.M.; Corniola, R.S.; Alshingiti, A.; Levenson, C.W. Zinc deficiency induces depression-like symptoms in adult rats. Physiol. Behav. 2008, 95, 365-369. [CrossRef] [PubMed]

63. Tamano, H.; Kan, F.; Kawamura, M.; Oku, N.; Takeda, A. Behavior in the forced swim test and neurochemical changes in the hippocampus in young rats after 2-week zinc deprivation. Neurochem. Int. 2009, 55, 536-541. [CrossRef] [PubMed]

64. Watanabe, M.; Tamano, H.; Kikuchi, T.; Takeda, A. Susceptibility to stress in young rats after 2-week zinc deprivation. Neurochem. Int. 2010, 56, 410-416. [CrossRef] [PubMed]

65. Nelson, D.R.; Wolff, W.A.; Blodgett, D.J.; Luecke, B.; Ely, R.W.; Zachary, J.F. Zinc deficiency in sheep and goats: Three field cases. J. Am. Vet. Med. Assoc. 1984, 184, 1480-1485. [PubMed]

66. Johnson, S.A.; Fournier, N.M.; Kalynchuk, L.E. Effect of different doses of corticosterone on depression-like behavior and HPA axis responses to a novel stressor. Behav. Brain Res. 2006, 168, 280-288. [CrossRef] [PubMed]

67. Zhao, Y.; Ma, R.; Shen, J.; Su, H.; Xing, D.; Du, L. A mouse model of depression induced by repeated corticosterone injections. Eur. J. Pharmacol. 2008, 581, 113-120. [CrossRef] [PubMed]

68. DeCarolis, N.A.; Eisch, A.J. Hippocampal neurogenesis as a target for the treatment of mental illness: A critical evaluation. Neuropharmacology 2010, 58, 884-893. [CrossRef] [PubMed] 
69. Snyder, J.S.; Soumier, A.; Brewer, M.; Pickel, J.; Cameron, H.A. Adult hippocampal neurogenesis buffers stress responses and depressive behaviour. Nature 2011, 476, 458-461. [CrossRef] [PubMed]

70. Fitzsimons, C.P.; van Hooijdonk, L.W.; Morrow, J.A.; Peeters, B.W.; Hamilton, N.; Craighead, M.; Vreugdenhil, E. Antiglucocorticoids, neurogenesis and depression. Mini. Rev. Med. Chem. 2009, 9, $249-264$. [CrossRef] [PubMed]

71. Yucel, A.; Yucel, N.; Ozkanlar, S.; Polat, E.; Kara, A.; Ozcan, H.; Gulec, M. Effect of agomelatine on adult hippocampus apoptosis and neurogenesis using the stress model of rats. Acta Histochem. 2016, 118, $299-304$. [CrossRef] [PubMed]

72. Suh, S.W.; Won, S.J.; Hamby, A.M.; Yoo, B.H.; Fan, Y.; Sheline, C.T.; Tamano, H.; Takeda, A.; Liu, J. Decreased brain zinc availability reduces hippocampal neurogenesis in mice and rats. J. Cereb. Blood Flow Metab. 2009, 29, 1579-1588. [CrossRef] [PubMed]

73. Whiteford, H.A.; Peabody, C.A.; Thiemann, S.; Kraemer, H.C.; Csernansky, J.G.; Berger, P.A. The effect of age on baseline and postdexamethasone cortisol levels in major depressive disorder. Biol. Psychiatry 1987, 22, 1029-1032. [CrossRef]

74. Starkman, M.N.; Gebarski, S.S.; Berent, S.; Schteingart, D.E. Hippocampal formation volume, memory dysfunction, and cortisol levels in patients with Cushing's syndrome. Biol. Psychiatry 1992, 32, 756-765. [CrossRef]

75. Wróbel, A.; Serefko, A.; Wlaź, P.; Poleszak, E. The effect of imipramine, ketamine, and zinc in the mouse model of depression. Metab. Brain Dis. 2015, 30, 1379-1386. [CrossRef] [PubMed]

76. Maes, M.; de Vos, N.; Demedts, P.; Wauters, A.; Neels, H. Lower serum zinc in major depression in relation to changes in serum acute phase proteins. J. Affect. Disord. 1999, 56, 189-194. [CrossRef]

77. Maes, M.; Vandoolaeghe, E.; Neels, H.; Demedts, P.; Wauters, A.; Meltzer, H.Y.; Carlo, A.; Roger, D. Lower serum zinc in major depression is a sensitive marker of treatment resistance and of the immune/inflammatory response in that illness. Biol. Psychiatry 1997, 42, 349-358. [CrossRef]

78. Siwek, M.; Dudek, D.; Paul, I.A.; Sowa-Kućma, M.; Zieba, A.; Popik, P.; Pilc, A.; Nowak, G. Zinc supplementation augments efficacy of imipramine in treatment resistant patients: A double blind, placebo-controlled study. J. Affect. Disord. 2009, 118, 187-195. [CrossRef] [PubMed]

79. Ranjbar, E.; Kasaei, M.S.; Mohammad-Shirazi, M.; Nasrollahzadeh, J.; Rashidkhani, B.; Shams, J.; Mostafavi, S.A.; Mohammadi, M.R. Effects of zinc supplementation in patients with major depression: A randomized clinical trial. Iran. J. Psychiatry 2013, 8, 73-79. [PubMed]

80. Młyniec, K.; Budziszewska, B.; Reczyński, W.; Doboszewska, U.; Pilc, A.; Nowak, G. Zinc deficiency alters responsiveness to antidepressant drugs in mice. Pharmacol. Rep. 2013, 65, 579-592. [CrossRef]

81. Mlyniec, K. Zinc in the glutamatergic theory of depression. Curr. Neuropharmacol. 2015, 13, 505-513. [CrossRef] [PubMed]

82. Manosso, L.M.; Moretti, M.; Colla, A.R.; Ribeiro, C.M.; Dal-Cim, T.; Tasca, C.I.; Rodrigues, A.L. Involvement of glutamatergic neurotransmission in the antidepressant-like effect of zinc in the chronic unpredictable stress model of depression. J. Neural Transm. 2016, 123, 339-352. [CrossRef] [PubMed]

83. Liu, J.; Raine, A. The effect of childhood malnutrition on externalizing behavior. Curr. Opin. Pediatr. 2006, 18, 565-570. [CrossRef] [PubMed]

84. Walsh, W.J.; Isaacson, H.R.; Rehman, F.; Hall, A. Elevated blood copper/zinc ratios in assaultive young males. Physiol. Behav. 1997, 62, 327-329. [CrossRef]

85. Penland, J.G.; Sandstead, H.H.; Alcock, N.W.; Dayal, H.H.; Chen, X.C.; Li, J.S.; Zhao, F.; Yang, J.J. A preliminary report: Effects of zinc and micronutrient repletion on growth and neuropsychological function of urban Chinese children. J. Am. Coll. Nutr. 1997, 16, 268-272. [CrossRef] [PubMed]

86. Sandstead, H.H.; Penland, J.G.; Alcock, N.W.; Dayal, H.H.; Chen, X.C.; Li, J.S.; Zhao, F.; Yang, J.J. Effects of repletion with zinc and other micronutrients on neuropsychologic performance and growth of Chinese children. Am. J. Clin. Nutr. 1998, 68, 470S-475S. [PubMed]

87. Iwasaki, K.; Satoh-Nakagawa, T.; Maruyama, M.; Monma, Y.; Nemoto, M.; Tomita, N. A randomized, observer-blind, controlled trial of the traditional Chinese medicine Yi-Gan San for improvement of behavioral and psychological symptoms and activities of daily living in dementia patients. J. Clin. Psychiatry 2005, 66, 248-252. [CrossRef] [PubMed] 
88. Monji, A.; Takita, M.; Samejima, T.; Takaishi, T.; Hashimoto, K.; Matsunaga, H. Effect of yokukansan on the behavioral and psychological symptoms of dementia in elderly patients with Alzheimer's disease. Prog. Neuropsychopharmacol. Biol. Psychiatry 2009, 33, 308-311. [CrossRef] [PubMed]

89. Matsuda, Y.; Kishi, T.; Shibayama, H.; Iwata, N. Yokukansan in the treatment of behavioral and psychological symptoms of dementia: A systematic review and meta-analysis of randomized controlled trials. Hum. Psychopharmacol. 2013, 28, 80-86. [CrossRef] [PubMed]

90. Pan, Y.J.; Wu, C.S.; Gau, S.S.; Chan, H.Y.; Banerjee, S. Antipsychotic discontinuation in patients with dementia: A systematic review and meta-analysis of published randomized controlled studies. Dement. Geriatr. Cogn. Disord. 2014, 37, 125-140. [CrossRef] [PubMed]

91. Nagaratnam, N.; Lewis-Jones, M.; Scott, D.; Palazzi, L. Behavioral and psychiatric manifestations in dementia patients in a community: Caregiver burden and outcome. Alzheimer Dis. Assoc. Disord. 1998, 12, 330-334. [CrossRef] [PubMed]

92. Tanji, H.; Ootsuka, M.; Matsui, T.; Maruyama, M.; Nemoto, M.; Tomita, N. Dementia caregivers' burdens and use of public services. Geriatr. Gerontol. Int. 2005, 5, 94-98. [CrossRef]

93. Mirakhur, A.; Craig, D.; Hart, D.J.; Mcllroy, S.P.; Passmore, A.P. Behavioural and psychological syndromes in Alzheimer's disease. Int. J. Geriatr. Psychiatry 2004, 19, 1035-1039. [CrossRef] [PubMed]

94. Steele, C.; Rovner, B.; Chase, G.A.; Folstein, M. Psychiatric symptoms and nursing home placement of patients with Alzheimer's disease. Am. J. Psychiatry 1990, 147, 1049-1051. [PubMed]

95. Ikarashi, Y.; Iizuka, S.; Imamura, S.; Yamaguchi, T.; Sekiguchi, K.; Kanno, H. Effects of Yokukansan, a traditional Japanese medicine, on memory disturbance and behavioral and psychological symptoms of dementia in thiamine-deficient rats. Biol. Pharm. Bull. 2009, 32, 1701-1709. [CrossRef] [PubMed]

96. Takeda, A. Insight into glutamate excitotoxicity from synaptic zinc homeostasis. Int. J. Alzheimer Dis. 2011, 2011, 491597. [CrossRef] [PubMed]

97. Takeda, A.; Itoh, H.; Tamano, H.; Yuzurihara, M.; Oku, N. Suppressive effect of Yokukansan on excessive release of glutamate and aspartate in the hippocampus of zinc-deficient rats. Nutr. Neurosci. 2008, 11, 41-46. [CrossRef] [PubMed]

98. Tamano, H.; Kan, F.; Oku, N.; Takeda, A. Ameliorative effect of Yokukansan on social isolation-induced aggressive behavior of zinc-deficient young mice. Brain Res. Bull. 2010, 83, 351-355. [CrossRef] [PubMed]

99. Takeda, A.; Iwaki, H.; Ide, K.; Tamano, H.; Oku, N. Therapeutic effect of Yokukansan on social isolation-induced aggressive behavior of zinc-deficient and pair-fed mice. Brain Res. Bull. 2012, 87, 551-555. [CrossRef] [PubMed]

100. Tamano, H.; Yusuke, E.; Ide, K.; Takeda, A. Influences of Yokukansankachimpihange on aggressive behavior of zinc-deficient mice and actions of the ingredients on excessive neural exocytosis in the hippocampus of zinc-deficient rats. Exp. Anim. 2016. [CrossRef] [PubMed]

101. Diz-Chaves, Y.; Gil-Lozano, M.; Toba, L.; Fandiño, J.; Ogando, H.; González-Matías, L.C.; Mallo, F. Stressing diabetes? The hidden links between insulinotropic peptides and the HPA axis. J. Endocrinol. 2016. [CrossRef] [PubMed]

102. Młyniec, K.; Budziszewska, B.; Holst, B.; Ostachowicz, B.; Nowak, G. GPR39 (zinc receptor) knockout mice exhibit depression-like behavior and CREB/BDNF down-regulation in the hippocampus. Int. J. Neuropsychopharmacol. 2015, 18, pyu002. [CrossRef] [PubMed]

103. Huang, Y.L.; Supasai, S.; Kucera, H.; Gaikwad, N.W.; Adamo, A.M.; Mathieu, P.; Oteiza, P.I. Nutritional marginal zinc deficiency disrupts placental 11ß-hydroxysteroid dehydrogenase type 2 modulation. Food Funct. 2016, 7, 84-92. [CrossRef] [PubMed]

(C) 2016 by the authors; licensee MDPI, Basel, Switzerland. This article is an open access article distributed under the terms and conditions of the Creative Commons Attribution (CC-BY) license (http:/ / creativecommons.org/licenses/by/4.0/). 